\title{
Food and Crime Fiction: Two Complementary Approaches to the Vietnamese Past in Tran-Nhut's Les travers du docteur Porc
}

\section{Tess Do, University of Melbourne}

Among today's diasporic authors of Vietnamese origins, Thanh-Van Tran-Nhut and her younger sister $\mathrm{Kim}^{1}$ emerged as true pioneers in the historical crime fiction genre when they made their literary debut in 1999 with Le temple de la grue écarlate. The novel featured a character inspired by their own great-grandfather, the mandarin Tân, a young and talented magistrate of Dai-Viet - the official name of Vietnam in the $17^{\text {th }}$ century. With eight novels currently to her name (the first two of which were signed by both sisters), Tran-Nhut has carved a comfortable niche for herself in the popular crime fiction market in France. She has obtained two awards - the Prix du Lion Noir 2008 for her sixth book, Les travers du docteur Porc (2007), and the Prix Thierry Jonquet for her eighth novel, Les corbeaux de la mi-automne (2011). Several of her books have been translated into Italian, Russian, Spanish, German and Japanese. What started as a game, a play of words and imagination, fictional events and characters, quickly became a lifechanging passion. The young Vietnamese-born French author was so enthusiastic about her writing that she abandoned her engineering career, travelling the world to gather material and publishing at the rate of one title every two years. This was a radical choice that (unlike Kim) she was prepared to make as early as 2004, after her fourth novel, even if she was not yet able to live by her pen: 'Mais je n'ai pas d'hésitation: si j'avais à

\footnotetext{
${ }^{1}$ In this paper, I refer to Thanh-Van Tran-Nhut as Tran-Nhut and to her younger sister Kim Tran-Nhut as Kim.

PORTAL Journal of Multidisciplinary International Studies, vol. 10, no. 2, July 2013.

Edible Alterities: Perspectives from La Francophonie Special Issue, guest edited by Angela

Giovanangeli and Julie Robert.

ISSN: 1449-2490; http://epress.lib.uts.edu.au/ojs/index.php/portal

PORTAL is published under the auspices of UTSePress, Sydney, Australia.
} 
choisir, je choisirais la vie tout court sur la vie professionnelle' (Mauvais genres 2004). ${ }^{2}$

In devoting her pen to historical crime fiction, Tran-Nhut has not simply led her French readers through ingenious murder plots; she has also taken them back in time and delighted them with the discovery of an exotic land and culture where the food and food habits of the Dai-Viet people, amongst other customs and Oriental science, figure prominently. Elaborate descriptions of food and its consumption pervade all her books to the point that they are now somewhat of a stylistic trademark. Unsurprisingly, their strong presence has not escaped the attention of readers. In one interview with the TranNhut sisters (Mauvais genres 2004), the first question asked was about food: 'D'où vient l'importance de la nourriture dans vos romans? Les héros passent un temps considérable à manger. Nous n'ignorons rien du détail de leur repas et nous avons même souvent droit à des recettes précises. ${ }^{3}$ Tran-Nhut's detailed and precise answer leaves no doubt as to why food is important to her or to how she intends its use in her books. Starting with the most obvious factor, she first remarks how the Vietnamese people enjoy eating and are seen snacking all day long, before moving on to explain how the descriptions of local food products that are unfamiliar to a Western reader can help lend an exotic touch to the setting of her stories, and finally pointing out how food can be an integral component of a murder plot. Poison, in fact, is one of Tran-Nhut's favourite means of murder. She has not only chosen the name of a poisonous flower (aconit or aconitum) to use as her email address (aconit23@free.fr), but she also admits that any occasion to use poison on her characters is good, whether they are sipping tea or feasting on food (Tran-Nhut 2009b: 108).

This essay offers a reading of Tran-Nhut's sixth novel, Les travers du Docteur Porc (2007), in which food and crime detection most conspicuously coalesce in the corpulent figure of Doctor Porc. In this novel, Porc, renowned acupuncturist, pharmacologist and forensic pathologist as well as notorious gourmand, glutton and intimate connoisseur of Vietnamese cuisine (otherwise limited to a supporting role), steps out of the shadow of the series' primary hero (the mandarin Tân) to adopt the mantle of Chief Detective and crime-solver. In this movement, we contend, two aspects of what can be viewed as

\footnotetext{
2 'But I would have no hesitation, if I had to choose between writing full-time and working as an engineer. I would simply choose life over professional life. All the English translations of Tran-Nhut's interviews and quotations from her novels in this article are my own, unless indicated otherwise.' 3 'Where does the importance of food come from in your novels? The heroes spend a considerable time eating. We don't miss any details of their meal and we are often even entitled to exact recipes.'
} 
Tran-Nhut's literary engagement with her past converge. On the one hand, the very process of 'solving the crime,' which provides both the raison d'être as well as the narrative structure of the work of detective fiction, can be equated with the restoration of order, normality and stability, after these have been violated (most commonly through violent criminal acts). In the same vein, the identification of perpetrators and the elucidation of underlying causes and motivations represent an attempt to make sense of the senseless and to seek atonement for the transgression. On the other hand, this ponderous sleuth's love of food firmly anchors the mechanism of what (in the Western tradition of the detective novel, at least) is commonly conceived of as an activity of logical, dispassionate ratiocination within a specific cultural and historical setting. In the figure of Porc, I argue, Tran-Nhut has sought to bring together contrasting elements of disruption and continuity, deliberately juxtaposing the violence of crime and the comfort of traditional gastronomic pleasures, and thus shaping perhaps one possible response to the war that has torn apart her birth country. This is above all a very different perspective from that provided by her primary hero, the mandarin Tân, dutybound to a doomed dynasty in a time of upheaval and war. In this essay, then, I investigate the perspective afforded by Porc by means of the motif of food.

\section{Mysterious menus: crime detection, cultural identity and food}

Most commentators would endorse Knight's observation that ' $[n]$ o detective is needed to identify the vigorous life and remarkable diversity of crime fiction' (2004: x), highlighting not only its wide-spread and enduring appeal, but also its ever increasing flexibility and variation (Todorov 1971; Scaggs 2005). 'Diversity' is also the term perhaps best suited to describing the 'lively and multifaceted body of work' (Pyrhönen 1994: 2) which in recent decades has been devoted to the genre. The blurring of the boundaries between so-called 'high' and 'low' literature (Porter 1981: 2; Pyrhönen 1994: 3), along with a perennial focus on the problematics of defining popular culture (Winks 1980: 1), has led to a wide range of analyses focussing on the genre's narrative structures or formal constraints as well as its capacity to either affirm or interrogate ideology and cultural stereotypes (or often some combination of the above). At the same time, both the popularity of the genre and the fact that the crime and its investigation take place 'within a social milieu' (Winks 1980: 3), has naturally 'focused attention on its relationship to the cultural context in which it is produced and read' (Winks 1980: 4). In this sense, Messent (1997: 2) highlights 'the importance and ongoing vitality of the 
debate about authority and individual agency, centrality and marginality, the law and its limits, and social system and individual criminal act' the genre has engendered, while suggesting that its ability 'to challenge dominant values and stereotypes' may well depend on the extent to which the writer can 'depart from the basic generic model' (1997: 17).

Increasing critical attention has been brought to bear on the question of identity in crime fiction - as amply evidenced by a number of recent edited volumes. As Krajenbrink and Quinn put it in their introduction to Investigating Identities:

\footnotetext{
Questions of identity have traditionally been central to crime and detective fiction. The term 'whodunnit' points to the importance of unmasking the criminal and identifying the wrongdoer. However, over time, questions of identity raised within the genre have become more complex. The quest to discover the identity of the person responsible for a particular crime has come, in many cases, to serve as a pretext for, or to provide a framework for a wider interrogation of society or of what constitutes criminality. The adaptability of the genre is such that it can be used to affirm or to undermine all concepts of identity, be these at the level of nation, ethnicity, culture, or at the level of gender or genre. (2009: 1)
}

Since the 'exotic and the foreign are the quintessence of mystery' and the Other or the Unknown 'demand to be encountered, investigated, decoded and, possibly, rejected,' Anderson, Miranda and Pezzotti find it unsurprising 'that foreign characters and foreign settings have had a privileged space in crime fiction since its origins' (2012: 1). While 'foreign victims, foreign sleuths, foreign settings or foreign criminals can provide a fertile ground for tackling issues of belonging, difference and national and regional identities,' it is particularly within the recent blurring of traditional distinctions, they assert, that the genre is able to negotiate these issues (1). Noting that 'crime fiction increasingly transcends, if not invalidates, national boundaries,' Matzke and Mühleisen (2006: 8) point to the fact that many authors have 'broadened the theme of investigation to address issues of community, beliefs and identity constructions across geographic and national boundaries, including gender and race relations,' but also emphasize the historical component inherent to any 'investigation into how colonial situations have been re-created and re-investigated from the perspective of the colonised.'

This last point resonates to a certain extent with a parallel repeatedly evoked by critics of the genre - namely that between the detective and the historian. Winks (1969: xiii), for example, emphasizes how both employ strikingly similar methods in order to collect, interpret and then explain their evidence, while Brown and Kreiser (2000: 4) extend the 
same parallel to the process of writing both historical and crime fiction. Their observation that both genres depend to a great extent on authentication by detail is echoed by Scaggs (2005: 4), who also emphasizes how 'descriptions of daily life, clothes, foods, houses, transportation, social activities, and more' are a vital tool in constructing the 'authenticity of the various periods' (126). In a similar vein, while discussing the historical novelist's ability to bring the past to life by giving body, voice, smells, colours and feelings to bygone people and places, Sarrot and Broche also indicate how a criminal investigation can provide the ideal excuse to 'pénétrer la vie intime des individus et les dessous d'une société, ... visiter les arrière-cours, s'arrêter aux petits détails qui font le quotidien' (2009: 108). ${ }^{4}$

This indicates a final point that has not escaped the critics' notice: the prominent and visible role played in crime fiction by food. This is evidenced on an obvious level by the significant number of compilations dedicated to the topic (Haining 1991; Manson 1994; Greenwood \& Pausacker 1995), as well as the fact that 'we almost always see the detective, in whatever novel, eating at one point or another' (McConnell 2009: 118). Greenwood and Pausacker (back cover) point to the fact that 'food is high on the murderer's list of handy ways to dispose of a murderee,' while McConnell sees evidence of crime fiction's obsession with the body, 'even to the point of the dark eroticism of the body's decay' (2009: 118). From a different perspective, Verdaguer emphasizes how 'mentions of food and cooking tend to complement the social backdrop of the story and reveal the milieu described by the author, very much in the nineteenthcentury tradition of realism,' but that they can also 'reflect the cultural orientation of novels, which range from ethnocentric to multiethnic' (2001: 187).

Even a cursory glance at the reviews of Tran-Nhut's novels confirms that her work is appreciated as both criminal and historical fiction, offering the Western reader not just a journey of discovery into another place and another time, but a window into another culture. These reviews rarely fail to evoke the 'exoticism' of her work or the unfamiliarity of an historical setting that most Western readers find very attractive (Meudal 2002; Mauvais genres 2004; Patzer 2008; Blanc 2008; Koß 2008; Keller 2008; Laherrère 2009). Tran-Nhut was well aware of this attraction when she explained the

\footnotetext{
4 'penetrate people's intimate life and the underbelly of a society ... visit the backyards, stop at details that make up everyday life.' My translation.
} 
success of her first book (Dupuis 2005):

Le premier livre a été bien accueilli, parce que c'était la première fois qu'on voyait une enquête se déroulant dans le Viêt-Nam du XVIIe siècle. Certes, le genre policier était déjà bien implanté, mais peu de gens connaissent le contexte historique, social ou religieux de ce pays à cette époque reculée. Il y avait ainsi une part de mystère associée à cette partie du monde qui a séduit pas mal de lecteurs.

Mentions of specific Vietnamese food and food habits are, I argue, more than the presentation of some gastronomic curiosities for the sake of an 'exotic' décor.

According to Barthes (2008: 32) 'an entire "world" (social environment) is present in and signified by food.' Through their food choice and culinary customs, the Vietnamese reveal who they are and how they see themselves in relation to others and the universe. As Fischler (2001: 68-69) points out: 'Les hommes marquent leur appartenance à une culture ou un groupe quelconque par l'affirmation de leur spécificité alimentaire ... L'homme mange pour ainsi dire, nous l'avons vu, à l'intérieur d'une culture, et cette culture ordonne le monde d'une manière qui lui est propre. ${ }^{, 6}$ To eat is therefore not just to feed oneself, but to enter a system of signs and symbols that shapes one's collective identity (Lévi-Strauss 1964). As Poulain argues (1997: 128) '[q]u’il soit perçu comme signe, emblème ou symbole, l'aliment insère le mangeur dans un système de significations. ${ }^{, 7}$ For a gourmand like Porc, who loves his Vietnamese food, eating is a meaningful act. In other words, there is more to his gluttony than just a personal péché mignon (indulgence).

This is why the juxtaposition of the motif of food and the practices of the criminal investigation gain significance in Tran-Nhut's novel Les Travers du Docteur Porc. Frequently compared to the mysteries of Judge Dee by the Dutch author Robert van Gulik, the mandarin Tân series is acclaimed as equally strange, if not more sensual and exotic, while the author herself is praised for having achieved a difficult balance between the demands of the crime fiction genre and the expected exoticism (Cosani n.d.; Meudal 2000; Grolleau 2004; Carloni 2005; Ferniot 2009;) However, for TranNhut who left her homeland in the thick of war at a very young age, and who is now

\footnotetext{
5 'The first book was well received because it was the first time that we saw an investigation take place in $17^{\text {th }}$ century Vietnam. The crime fiction genre was certainly well established, but few people know the historical, social or religious context of that country in that distant time. There was thus an element of mystery associated with that part of the world that has attracted many readers.'

${ }^{6}$ 'Human beings mark their belonging to a culture or a group by asserting their food specificity ... As we have seen, man eats so to stay inside a culture and that culture organizes the world in its own unique way.'

7 'whether it is seen as a sign, an emblem or a symbol, food places the eater in a system of meanings.'
} 
writing for a French audience from a French perspective, the choice of the period in which to set her fictional recreation of the land and traditions of her ancestors is not simply motivated by a desire for the exotic. In fact, it carries particular resonations, as she herself emphasizes. For the historical background of her heroes' detective exploits, the Trinh-Nguyen conflict, which led to the civil war, "la plus immonde des guerres" ${ }^{8}$ as she calls it (Mauvais genres 2004), dividing the country into two enemy states, North and South, characterises a historical period that bears a striking resemblance to the Vietnam War (1945-1975). ${ }^{9}$ As she explains at length:

\begin{abstract}
[n]ous avons choisi le XVIIe siècle parce que c'est un siècle d'effondrement et d'ouverture. Face à la corruption ambiante et aux luttes de pouvoir entre deux familles puissantes du nord et du sud, le système confucéen est en train de s'écrouler, tandis que l'arrivée des Européens le sape encore davantage avec l'introduction d'une nouvelle religion. L'exploitation économique par des puissances extérieures devient de plus en plus réelle, et une guerre civile est sur le point d'éclater. Cela semble familier? Effectivement, pour moi, tout attrait de cette époque provient de cette situation explosive qui annonce non seulement la colonisation française, mais aussi la guerre du Viêt-Nam avec la scission nord-sud. Trois siècles plus tôt, cette guerre avait déjà eu lieu. (Mauvais genres 2004) ${ }^{10}$
\end{abstract}

Here, however, we encounter a certain ambiguity, one that many commentators have identified as lying at the heart of the crime fiction genre. The process of investigating and solving the crime, or 'working backward from its visible effects to its hidden causes and to the concealed identity of the culprit' (Pyrhönen 1994: 9), makes certain assumptions about the nature of society and the world. As Winks puts it, those assumptions fundamentally make the genre 'conservative, almost compulsive in its belief (to which, of course, there are exceptions) that one may in truth trace cause and effect, may place responsibility just here, may pass judgment, may even assess blame, and in its determination not to let us forget that there is evil in the world and that men and women, individual men and women, do it' (1980: 10). In this sense it is (as least in its traditional form) often hopelessly idealistic, and indeed many of its so-called

\footnotetext{
8 'the dirtiest war.'

${ }^{9}$ Dieter Paul Rudolf (2008) points to this fact in his review of the German translation of Tran-Nhut's third novel Flucht in die Gegenwart [Flight into the Present]. He highlights the significance of the name Count Diệm, one of the novel's murder victims, and interprets the figure of the prison warden Madame Aconit [Frau Eisenhut] as simultaneously oppressor and benefactor, and thus as a symbol of Communism. 10 'We have chosen the $17^{\text {th }}$ century because it is a century of collapse and opening. Faced with the ambient corruption and the struggles for power between the two powerful families in the North and the South, the Confucian system is crumbling, while the arrival of the Europeans undermines it even further with the introduction of a new religion. The economic exploitation by the external powers becomes more and more real, and a civil war is about to explode. Does it sound familiar? Effectively, for me, all the attraction of this era comes from that explosive situation that heralds not only French colonisation, but also the Vietnam war with the North-South scission. Three centuries earlier, this war had already happened.'
} 
'Golden Age' practitioners are assumed in part to have been engaged in 'recreating the sense of a pastoral or pre-war innocence,' by creating a framework within which 'solving the mystery makes the world rational again' (Reid 1992: 55).

This tension is integral to the situation in which Tran-Nhut deliberately places her primary hero, the mandarin Tân. By purposely leaving him fighting for a lost cause at the end of the Lê Empire, Tran-Nhut has come close to exploring in fiction what she did not know of the war that sent her and her family to the USA in the bloodiest year of 1968: the haunting feeling of doom and despair, and the bitter taste of defeat of those who lost the war. As she explains, '[c]e n'est pas par hasard que nous avons laissé le mandarin Tân s'engager aux côtés des seigneurs Trinh du Nord: dans le camp des futurs vaincus, il se cramponne à ses idéaux et à ses espoirs, et se bat pour une cause perdue d'avance. Et l'amertume n'en est que plus tangible' (Mauvais genres 2004). ${ }^{11}$ Porc, on the other hand, is, as I will show, an exact counterpoint to Tân and thus offers a very different perspective on loss and despair. This perspective emerges from his 'double identity' as detective and gourmand.

\section{Porc, gourmand and detective}

From the very first book in the series, the corpulent character of Doctor Porc in his role as medical practitioner and forensic pathologist has allowed Tran-Nhut to pursue the theme of exotic food and food habits as cultural markers within the murder plot. In her sixth novel, Les travers du docteur Porc (2007), the Doctor is allowed to take centre stage, as the mandarin Tân temporarily confers his authority as a justice of the court upon him. The significance of his new role does not escape Fabrice Docher (n.d.) who comments: 'Axé cette fois-ci sur le personnage du docteur Porc, formidable praticien à l'humeur exécrable et à l'appétit démesuré; cela permet une approche différente de l'époque, avec une image plus précise de la cuisine, vraiment très étrange, et de la médecine. 12 The highly evocative title of the book itself immediately points to food while cleverly playing on the double meaning of the word les travers that, combined with Porc, ambiguously refers to both a cut of meat (pork ribs) as well as the character's

\footnotetext{
11 'it is not by chance that we let the mandarin Tân side with the Trinh Lords in the North: in the camp of the future losers, he is hanging on to his ideals and hopes, and is fighting for an already lost cause. And the bitterness is all the more tangible.'

12 'Centred this time on the character of the doctor Porc, formidable practitioner with an execrable mood and an excessive appetite; this allows for a different approach to the era, with a more precise image of the cuisine, that is really quite strange, and of the medicine.'
} 
faults. It is probably no coincidence that the character named Porc is portrayed as having characteristics commonly associated with the pig, such as greed and a large meaty body. Not only does Porc in French refer to both the animal and its meat, but its distinctive contrast to the Vietnamese names of his colleagues (for example, the mandarin Tân, the scholar Dinh, the palanquin bearers Xuân and Minh), seems to suggest that she wishes to flag this particular gourmand to her French readers. ${ }^{13}$

Distinguished by his voracious appetite, excessive eating and enormous body, Porc stands out between the thin, vegetarian Dinh and the muscular but moderate eater Tân. As a native of a country where 'gourmandise sans borne ${ }^{, 14}(247)$ is depicted as a prominent cultural trait, however, he perfectly fits the mental picture that Doctor Lakhbir, an Indian traveler, makes of the Dai-Viet people he sees:

\begin{abstract}
[C]e peuple exotique de petite taille ne cessait de l'émerveiller avec sa gourmandise sans borne. Il n'avait jamais pu mettre le nez dehors sans s'apercevoir quelque groupe agglutiné autour d'une marchande de friandises, s'empiffrant à en perdre haleine. Accroupis sur leurs talons, les Viêts maniaient furieusement baguettes et cuillères, enfournant à la va vite des bouchées de nourriture tout en pérorant avec frénésie. Il se demandait comment ils parvenaient à ingurgiter à la queue leu leu soupes et poissons, brochettes et gâteaux, nouilles et galettes, sans jamais s'étrangler sur un morceau rétif. $(247-48)^{15}$
\end{abstract}

As the virtual incarnation of what Tran-Nhut has described as a self-respecting Vietnamese from whose gustative curiosity no moving creature is safe (Mauvais genres 2004), Porc's peculiar tastes flag him as a locus of exotic food culture. If we consider, however, that 'exotic,' in the culinary field, will often refer to a taste, a food or a way of cooking that are considered attractive because they are seen as sufficiently, but not excessively, foreign to European culture (Régnier 2004: 22), then we will be in a better position to appreciate the role that Porc's food choices play in Tran-Nhut's narrative. Given that nowadays a large number of Asian produce such as the herbs and spices mentioned in Les travers du docteur Porc - rice, noodles, coconut, durian, ramboutan,

\footnotetext{
${ }^{13}$ Of all the recurring characters in Tran-Nhut's detective series, only Porc and Dinh made their way into one of Tran-Nhut's short stories, 'Amuse-gueules' [Appetisers], that is published in her collection on food and food experiences entitled Le palais du mandarin [The Palace of the Mandarin]. Porc's close association with Vietnamese food culture made him the star of 'Amuse-gueules' in which he brilliantly solves all the riddles put to him by Dinh.

14 'boundless gluttony.'

15 'This small-sized exotic people never ceased to amaze him with their boundless gluttony. He could hardly step outside without seeing groups of people gathering around a vendor of sweets and breathlessly stuffing themselves. Sitting on their heels, the Vietnamese were furiously handling chopsticks and spoons, quickly shovelling in mouthfuls of food while chatting away in a frenzied manner. He wondered how they could ingest one after another, soups and fish, skewers and cakes, noodles and pancakes, without ever choking on a stubborn piece of food.'
} 
mangosteen, starfruit, Chinese cabbage, gourd, lemongrass, coriander, chili, lime, sesame seeds - can be found in French supermarkets, and that typical Vietnamese dishes, such as springrolls and pho (beef noodle soup), are staples in Asian restaurants the world over, Tran-Nhut would have to go further than simply listing them in her book if she is to employ food in order to create an 'exotic' impression among her French readers. To this aim she has resorted to two strategies, the most obvious being the introduction of lesser known Vietnamese specialty dishes. As Tran-Nhut has herself mentioned, the Vietnamese culinary repertoire includes some dishes that are not so unusual for a Vietnamese, but that would appear quite alien to most Westerners in terms of taste and mental representation:

La nourriture permet d'apporter une touche exotique supplémentaire, car non seulement on cuisine avec des épices et des herbes spécifiques au pays (cardamome, cumin, curcuma, citronnelle ...), mais on ne craint pas non plus de les utiliser pour accommoder des bêtes diverses et variées. Ainsi, les écailles du fameux pangolin (celui-là même par qui le SRAS actuel est arrivé), les holothuries ou concombres de mer, les grillons, et même le modeste rat des champs. (Mauvais genres 2004) ${ }^{16}$

Porc's gargantuan appetite and iron stomach make his character ideally suited to introducing specialty dishes that would be recognizable to any Vietnamese, but remain unfamiliar to the French. True to his name, Porc is depicted eating and snacking at various times of the day, consuming no less than sixteen different dishes, from a halfdozen fertilized duck eggs and a dozen raw fermented pork pâté and garlic pork sausages as snacks, to a full dinner of offal soup with cow lung, fried, boiled and steamed coagulated blood cakes, and fried rice (Tran-Nhut 2007: 47). For lunch, his menu can vary from a quick meal of crispy fried pork skin and rice alcohol (162), chilli tripe soup with beef heart and pork fat cubes (163), to colourful sweet soup with lotus seeds, pomegranate pearls, coconut milk and gelatin for desert (165).

While items such as cow lung, beef heart or coagulated blood cakes may sound exotic to some readers, they are arguably not entirely anomalous to the French whose cuisine $d u$ terroir (local cuisine) boasts various recipes for tripe and boudin noir (blood pudding). One dish, however, certainly does stand out: the fertilized duck embryo. In fact, this particular delicacy has a history as a marker of peculiar foreign habits: over a century

\footnotetext{
16 'Food allows [me] to bring an additional exotic touch [to my stories] because in Vietnam one not only cooks with spices and herbs that are specific to the country (cardamom, cumin, curcuma, lemongrass ...), but one is not afraid to use them to prepare different kinds of animals. Like, the scales of the famous pangolin (from which the virus SARS came), holothurians or sea cucumbers, crickets, and even the humble field rat.'
} 
ago, it was described in some detail by De la Bissachère (1812: 225), who could conceive of no sensible explanation as to why incubated and nearly-hatched eggs were preferred to fresh eggs. For him it was evident that this bizarre taste set the Tonkinese apart from all other peoples:

Par un goût contraire à celui de toutes les autres nations, on n'aime point les oeufs frais, on donne la préférence à ceux qui ont été couvés et qui sont prêts à éclore: c'est un manger très-recherché par les gourmands, qui trouvent un grand plaisir à sentir les os de l'animal à demi formés croquer sous la dent. ${ }^{17}$

The fact that a slight variation of the same dish has found its way into a book suggestively entitled La cuisine abominable: L'Asie en 100 recettes incroyables mais vraies attests to the borderline-repulsive unfamiliarity it retains today, with the authors, Casazza and Vuillemin, taunting their French readers' sensibilities with a description of the same 'bone-crunching' experience (2011: 68). Compare this to Tran-Nhut's description of Porc's consumption (and enjoyment) of this particular dish: 'Il se mit à casser la coquille piqueté de marron. A l'intérieur, une boule de plumes attendait qu'on la déguste avec des feuilles de renouée odorante au goût poivré. Assaisonné avec une poignée de sel, le caneton en devenir fondit joyeusement sous les molaires du docteur Porc, qui enchaîna prestement sur un deuxième compagnon' (Tran-Nhut 2007: 97). ${ }^{18}$ Where we might expect an emphasis on exoticism, we find familiarity. Something that seems predestined to 'shock' the reader's sensibilities is used to create a warm, even intimate ambience of comfort, contentment and succour. What we find here is the consumption and appreciation of Vietnamese culture by a Vietnamese born and bred, shorn of the Western associations and perspectives often aggregated under the term 'exoticism.' Doctor Porc shows his true (cultural) colours: when he is eating (Vietnamese) food he is fully himself and completely at home.

If to a Western reader Porc's unusual food preferences would seem to mark him as a locus of the exotic, from a Vietnamese perspective those preferences primarily identify him as a culture bearer, insofar as his tastes and eating habits are presented as typically Vietnamese. In this sense he is not only a connoisseur, but an expert and authority on

\footnotetext{
17 'With a taste preference that is opposite to that of all other nations, one does not like fresh eggs at all, preferring those that have been sat on and are ready to hatch: it's a highly sought after food by the gourmands who find great pleasure in feeling the bones of the half-formed animal crack between their teeth.'

${ }^{18}$ 'He started to break the spotty brown shell. Inside, a feather ball was waiting to be enjoyed with fragrant, peppery hot mint. Seasoned with a pinch of salt, the duckling-to-be melted merrily under the molars of Doctor Porc, who moved on swiftly to the second fellow.'
} 
local cuisine. Nowhere is this more evident than in a pivotal encounter between Porc and Lakhbir, an Indian migrant and fellow medical practitioner. When both Porc and Lahkbir cast a covetous eye on the same top-location property, the owner's decision to sell the property to the winner of a competition staged by himself pits the two men of science against one another in a battle of medical skill, one in which Lahkbir proves to be Porc's equal. When it comes to food, however, the latter indubitably has the upperhand. Determined to win the competition, Porc tries to disconcert his rival and discourage him from settling in Dai-Viet by introducing him rather brutally to what he regards as 'national tastes': 'Pour peu que ses entrailles se révoltent contre les saveurs nationales, ce dernier [Lakhbir] déciderait d'élire domicile dans une contrée plus avenante, abandonnant du coup l'échoppe sans le moindre regret' (129). ${ }^{19}$ Pretending to play host to his rival, Porc subjects Lakhbir to 'son cours d'initiation à la nourriture viêt' (129), ${ }^{20}$ taking him to a little hash-house where the shop sign depicting a 'cochon souriant aux jarrets massifs et à la couenne épaisse' $(123)^{21}$ unsettles the Indian. Literally in the realm of the Pig/Porc and set against backdrop of the Vietnamese patrons who seem to be particularly fond of entrail soup and capon, Lakhbir sticks out sorely as the Other, not only because of his different clothes and physical appearance but because of his complete unfamiliarity with the Vietnamese specialities that Porc has ordered and his inability to appreciate them: caramelized pork with sesame seeds; lemongrass beef soup with pig trotter; stuffed gourd soup with coriander; stir-fried mustard leaves with hot chilli; preserved bean sprouts in brine; and half a fresh durian for dessert (124).

Tellingly, Tran-Nhut describes this particular food experience through the eyes of the foreigner, contrasting his reaction of shock to Porc's obvious gastronomic delight. In contrast to her description of the fertilized duck eggs, she now highlights each dish's unfamiliar appearance, taste and smell, drawing, for example, an unappetizing analogy between ordinary stuffed gourds and the "courges variqueuses"22 (125) that Lakhbir encounters: 'on pratique une longue incision, on bourre la cavité et on recoud avec du gros fil' (125). ${ }^{23}$ Unsurprisingly, this initiation to Vietnamese specialties is a real taste-

\footnotetext{
19 'If the national tastes upset his stomach, the latter [Lakhbir] would decide to take up residence in a more prepossessing land, thus giving up the workshop without any regret.'

20 'his initiation course to Vietnamese food.'

21 'smiling pig with massive hocks and thick rind.'

22 'varicosed squashes.'

23 'one makes a long incision, one stuffs the cavity and one sews it back with a thick thread.'
} 
bud booby-trap for the unwary foreigner. Lakhbir burns his tongue on 'un morceau de piment particulièrement virulent' $(126)^{24}$ while munching on an innocent looking mustard leaf, and nearly has a heart attack while sampling the stuffed gourd soup, whose extremely bitter taste catches him completely by surprise.

The otherwise successful Indian doctor's unfamiliarity with the local food begins to suggest his unfamiliarity with local medical practices, allowing Porc to take the lead in the contest and to explain the locals' strange appetities for the soup's flavour, by pointing out that '[1]e goût amer permet de réduire la sensation de chaleur et s'avère très utile pour combattre la constipation' (125-26). ${ }^{25}$ Nowhere is the notion of 'belonging' or 'being at home' more conspicuously associated with Porc than in this culinary encounter between the two rival medical practitioners. At the same time, it is important to note that Porc's familiarity with the medicinal properties of the bitter gourd not only identifies him as an adept of traditional Vietnamese medicine but also as a brilliant forensic pathologist who draws upon his 'scientific' and his traditional medical knowledge in the course of his criminal investigations. Porc's intellectual acumen is often closely linked to his intimate (insider's) acquaintance with Vietnamese food and eating practices. In this particular scene-foreshadowing in a sense the way that Porc will recognise the poisonous berries that come from a local plant called cam thao day or tuong tu tu (Abrus precatorius) used by the murderers (103)_-Porc's acumen is in fact epitomized by the pinnacle and culmination of their dubious feast: the durian, probably one of the most exotic species of the fruit kingdom in the eyes of most Westerners.

Hailed as the 'King of fruits' throughout Southeast Asia, the durian's strong and unpleasant smell makes it utterly foreign to the Western palate, even though the fruit itself is no longer unknown in the West. Understandably, Lakhbir's reaction is similar to that one would expect from any durian non-eater, turning livid when he sees the mysterious sâu-riêng placed in front of him: 'La serveuse ... déposa un fruit hérissé de piquants, coupé en deux, qui libérait de généreux effluves ressemblant étrangement à ceux de sous-vêtements pourris. Blême, le docteur Lakhbir fixait la chair jaunâtre et molle qui s'offrait à ses papilles' (128). ${ }^{26}$ Here, Tran-Nhut's use of the Vietnamese term,

\footnotetext{
24 'a piece of fiery hot chilli.'

25 'the bitter taste reduces the sensation of heat and turns out to be very useful to combat constipation.'

26 'The waitress ... put down a thorny fruit, cut in half, whose generous exhalations strangely resembled those of rotten underwear. Pale, the doctor Lakhbir stared at the yellowish and flabby flesh that offered
} 
sâu-riêng, printed in italics, conflates the Indian character and the French readers in the position of the non-Vietnamese foreigners. As such, the term certainly invests the French text with an extra exotic touch: 'Les termes en langue étrangère accroissent l'effet d'exotisme et ils font rêver, par le mystère qu'ils introduisent' states Régnier (2004: 167). ${ }^{27}$

Arguably, however, the primary function of the durian in this scene is not so much to evoke exoticism, but rather to highlight Porc's status as a cognoscente of specifically Vietnamese culture. As Matty Chiva (1993) has pointed out, '[1]a qualité hédonique d'une odeur, au-delà des spécificités de chaque individu, est fonction des règles et usages culturels ... Le consommable et le non-consommable sur le plan alimentaire est, en très grande partie, une décision culturelle. ${ }^{28}$ The extreme reactions elicited by the durian's smell and taste become an effective marker of alterity, contrasting those from the West, who generally find the durian to be disgusting, to those from Southeast Asia, who find it heavenly-like Tran-Nhut herself who enjoys the succulent flavour of the durian ice-cream and is sceptical that any Vietnamese person would complain about its odour. $^{29}$ The same theme of alterity has also been exploited by Kim Lefèvre, a Eurasian writer born in Vietnam. Like Tran-Nhut, Lefèvre (1990: 38) achieves the same impression of being a cultural insider by contrasting her knowledge of the durian (for example, she can tell when it is ready to eat just by its smell and knows how to open it by dropping it on the floor) with the way her French friend threw away the ripe, smelly fruit, mistaking it for a rotten one.

Tran-Nhut has made several references to the durian in two other books, first in the debut detective novel Le temple de la grue écarlate (1999), and again in Le palais $d u$

\footnotetext{
itself to his taste buds.'

27 'The foreign terms increase the exotic effect and make one dream by the mystery they introduce.'

28 'the hedonistic quality of a smell, beyond the specificities of each individual, depends on the cultural rules and customs ... When it comes to food what is fit and unfit for human consumption is, to a very large extent, a cultural decision.'

${ }^{29}$ In a short story 'Le bol fumant de la félicité' published online in the French newspaper Libération, Tran-Nhut (2009a) is not convinced that Vietnamese people would find the durian's smell unbearable, in the same way as it is highly unlikely that they would find the fish sauce nuoc-mâm pungent: 'Il y a donc des Viêts qui font la fine bouche devant ce fruit tropical? La véhémence du patron me laisse sceptique: il paraît qu'autrefois, pour faire comme les Français, certains Viêts s'empressaient de dénigrer publiquement le nuoc-mâm national, tout en consommant—en cachette — cette sauce de poisson fermenté par bouteilles entières' [So there are Vietnamese who turn their nose up at this tropical fruit? The shopkeeper's vehemence makes me sceptical: it seems that in the past, in order to act like the French, some Vietnamese were quick to publicly denigrate the national nuoc-mâm, while secretly consuming that fermented fish sauce by the bottles].
} 
mandarin (2009b), published in Chantal Pelletier's collection Exquis d'écrivains. ${ }^{30}$ In

both instances, however, the fruit appears not primarily as an edible object, but rather as the subject of a mystery to be solved. ${ }^{31}$ In these works, solving the Riddle of the Durian - along with a host of similar brainteasers involving Asian items such as the Riddle of the Coconut, the Catfish, the Chopsticks and the Mandarin's Square-Tip Boots - pose specifically Vietnamese puzzles, a feature consonant with the concept of 'solving the mystery of Vietnam's past' discussed in the introduction to this paper.

Tellingly, it is Porc's intimate familiarity with Vietnamese culture and food that in this scene allows him to win this particular round of the two doctors' 'battle of wits.'

\section{The vast belly of Porc}

It is in front of this background, we argue, that Porc's temporary role as Chief Detective reveals more (and deeper) dimensions than immediately meet the eye. This begins with the implications of his selection as Tân's replacement rather than Dinh, the magistrate's right-hand man. While he has a prodigious memory and has proven many times to be an invaluable aid to Tân's investigations, Dinh, an officer of the court, is bound by the court protocol. In sharp contrast to him Porc is an independent, self-employed doctor who runs his own medical clinic and earns his own living without any official obligations. Amongst Tân's close circle of friends and assistants, he is the only one whose professional services are to be solicited rather than formally required by the court, having no attachment or duty to the Emperor or anyone else. If he has agreed to look after the tribunal during Tân's and Dinh's absence, an agreement he bitterly regrets later, it is because the magistrate flattered his ego by relying on his wisdom and intelligence and leaving him the full authority over the court officers (Tran-Nhut 2007: 27). Both Tân and Porc are men of considerable intellect, whose crime-solving acumen serves to restore the peace and mete out justice (Porc single-handedly solves two

\footnotetext{
${ }^{30}$ Chantal Pelletier (n.d.) describes her collection as a '[p]etite bibliothèque gourmande contemporaine ... [qui invite] des auteurs contemporains d'horizons très différents de donner libre cours à leur imagination gourmande' [little contemporary gourmand library ... (that invites) contemporary authors from diverse horizons to give free rein to their gourmand imagination]

${ }^{31}$ In Le Temple de la grue écarlate the riddle of the durian runs as follows: 'Gare à vous, jeune homme,/Si vous me touchez le dard./ Ecartez pourtant mon vêtement rude/ Et je vous laisserai lécher/ Mon ventre humide et sucré' [Watch out, young man, if you touch my dart. Pull off my rough garment, and I will let you lick my sweet and moist belly] (Tran-Nhut 1999:188). In Le palais du mandarin the durian is described in these terms: 'Je suis gros, avec un ventre mou,/ Mon haleine fétide inspire le dégoût./ Pourtant, si vous souffrez du froid,/ Remettez-vous à mes soins./ Venez, Mesdames, déshabillezmoi,/ Et vous serez émerveillées/ Par ma douceur de soie!' [I am big, with a soft belly, my foul breath inspires disgust. Yet, if you suffer from cold, put yourself in my care. Come on, ladies, undress me, and you will be amazed by my silky softness!] (Tran-Nhut 2009b: 43-44).
} 
murder cases, all the while engaging in a medical duel with Lakhbir), but there is also a stark contradistinction between the gourmand with the 'boundless appetite' and the loyal, duty-bound Confucian mandarin. While Tân's honour and raison d'être lie in serving the Emperor selflessly and unquestioningly, Porc sees 'un honneur que de se dévouer aveuglément à l'Empire' (246), ${ }^{32}$ being of the opinion that the nation has to reward its most worthy sons (245-46). If he has agreed to investigate the cold case murder that is brought to him by Tân's myrmidons, it is because he is tricked (and tempted) to believe that the magistrate will thank him with a hefty reward, a gold ingot, rather than being motivated by the mission to serve (the Emperor's) justice.

Unencumbered by Confucian principles and having few illusions about the morality and righteousness of men (or kings), Porc displays a more realistic view than the idealist Tân. When it comes to the question of whether to remain blindly loyal to the corrupted Lê Dynasty, and be eventually sacrificed in its inevitable fall, or whether to side with the people to welcome the new Nguyen ruler, one can expect to see him walk out of the moral dilemma unruffled while Tân's fate is sealed for he simply cannot betray his Emperor without betraying his moral principles. As Tran-Nhut explains in one of her interviews:

\begin{abstract}
Le confucianisme, pierre angulaire du monde d'alors, garantit la stabilité de la société en mettant en avant le devoir collectif au détriment de la liberté individuelle. Or, ce système n'est défendable que si l'on suppose que l'empereur et toutes les strates de la société sont incorruptibles. Ce qui est loin d'être vrai. Au cours de ses enquêtes, le mandarin s'apercevra que les crimes commis trouvent leur raison dans la perversion d'un tel système, et cela l'obligera à questionner le fondement même de la justice, qui est sa raison d'être. (Depuis 2005) (33 $^{33}$
\end{abstract}

Unlike Tân, Porc's allegiance is not to the dynasty, but rather to his own stomach. His appreciation of the Vietnamese food and tastes, his voracious appetite and his indulgence in gastronomic pleasures, from this perspective, reflect a refusal to be drawn into politics in a time of corruption and turmoil, to take sides in the Trinh-Nguyen conflict or to be distressed by the looming threat of revolution and civil war. Moreover, in the same way as war disrupts normal life, the double murders that occurred on his watch disrupt his carefree (and typical Vietnamese) way of life characterized by good

\footnotetext{
32 'no honour in devoting himself blindly to the Empire.'

33 'Confucianism, cornerstone of the ancient time, guarantees the stability of the society by foregrounding the collective duty to the detriment of the individual freedom. However, this system is only justified if one supposes that the emperor and all the strata of the society are incorruptible. This is far from true. In the course of his investigations, the mandarin will see that the crimes committed have their cause in the perversion of such a system, and this will force him to question the very foundation of justice that is his raison d'être.'
} 
food and the pleasures of eating. Because of the urgency of his investigation, Porc is often prevented from going out for a leisurely dinner as he usually does in one of the many lively chophouses in the town market. Instead, he is obliged to stay back late at night in the archives room to catch up with his reading of the court files. Frequently, he has to snack on the spot or have his food delivered to him by the mandarin's servants (Tran-Nhut 2007: 97). Only the perspective of having his copious and delicious meals fully covered by the court can bring him some consolation:

Le médecin s'attaquait avec appétit au bouillon odorant dans lequel surnageait un morceau de poumon de bœuf. Il mordit ensuite dans un carré de sang coagulé qui craqua agréablement sous ses canines aiguisés. Voilà de quoi le dédommager d'une soirée passée au tribunal à essayer de débrouiller une mystérieuse affaire de disparue! $(47)^{34}$

Seen as such, this cold case is the first of a series of murders that '[sèment] le désordre' $(29)^{35}$ in his everyday life and disrupts the daily round of the court officers left in his care by Tân. Solving the crime will allow Porc to remove the disruptive, stressful factor that upsets his normal eating routine and revert back to his easy (pre-crime) lifestyle. This seems to correspond to how the Vietnamese people regard eating as a sacrosanct activity that should not be disturbed by anyone or anything, including Heaven itself. ${ }^{36}$ Throughout his investigation, food functions as a continual source of physical comfort that Porc can rely on in a time of mental stress. Indeed, whenever he can have a break from his investigative work, Porc gratifies himself with the pleasure of eating:

\begin{abstract}
A peine [la serveuse] eut-elle posé le bol rempli d'un bouillon parfumé qu'il s'emparait des baguettes et commençait à repêcher les lambeaux de tripes qui nageaient au milieu des morceaux de cœur de bœuf. Après avoir y ajouté quelques tranches de piment, il savoura les nouilles accompagnées d'une gorgée de liquide brûlant et poussa un soupir de satisfaction. Heureusement qu'il lui restait encore ces menus plaisirs! Une nourriture saine au secours d'un moral qui flanche. $(163)^{37}$
\end{abstract}

In this sense, Porc is the character who allows Tran-Nhut to revisit Vietnam's turbulent past in a way that her hero Tân cannot. Food itself, so it seems, has the double magical

\footnotetext{
34 'The doctor dug heartily into his fragrant broth in which a piece of cow lung was floating. He bit into a block of coagulated blood that cracked pleasantly under his sharp teeth. Now that's something to compensate himself for the evening spent in the court trying to unravel a mysterious case of a missing woman!'

35 'sow the seeds of disorder.'

${ }^{36}$ An old Vietnamese saying runs as follows: 'Even Heaven avoids striking people when they are eating.'

37 'Hardly had [the waitress] placed the bowl full of a fragrant soup that he snatched his chopsticks and started to fish out the fragments of tripe that were swimming in the midst of the beef heart pieces. After having added some chilli slices to his soup, he savoured the noodles with a sip of the hot broth and let out a sigh of satisfaction. How fortunate that he still had these tiny pleasures! A wholesome food to the rescue of a feeble morale.'
} 
power of dissolving problems and conflicts, and restoring Porc's good mood and high spirits because 'rien qui ne puisse se résoudre en se régalant d'une succulente soupe aux abats' (162). ${ }^{38}$ If we read his huge belly with its incredible capacity to digest and find great pleasures from any kind of food, from the fragrant to the pungent, the sweet to the sour, the salty to the bitter, the hot to the mild, without ever becoming sick (in contrast to his many patients who suffer from indigestion and food poisoning) as a metaphor of an absorption of past memories, we can suggest that through Porc, Tran-Nhut may have found a way to come to terms with Vietnam's turbulent history. Intimately associated with Vietnamese food and the joy of eating, he is the only significant character that allows Tran-Nhut to counterbalance the bitter taste of the war with the brighter and happier side of the past. Perhaps like Lakhbir who, at the moment of leaving Dai-Viet, remembers Porc with fondness in spite of his egocentricity, Tran-Nhut, too, would like to keep a fond memory of her birth country, in spite of the war that wrought chaos and bloodshed in it for thirty years. ${ }^{39}$ In devoting a whole detective book to showcasing Porc as both a brilliant investigator and a gourmand who can, at any point in time, also find solace and strength in his beloved cuisine, she may have done just that.

Rather than putting his faith in kings and kingdoms, doctrines and ideologies, that come and go with the ebb and flow of history, Porc has chosen to go back to something that is more basic, more enduring and of more lasting value: food, because it is a basic human need, and culture, because it is embedded in the Vietnamese people's way of life. While engaged in intellectual activities, searching for answers and dealing with the consequences of crime, these provide both comfort and stability. And these remain, despite the war and the loss of so much, including everything that the mandarin Tân fought for. The 'crime' of the war may never be solved in the neat, clean manner a detective novel might traditionally demand, but Porc's source of succour has not been lost.

\footnotetext{
38 'after all, there is nothing that cannot be resolved while savouring a delicious offal soup.'

${ }^{39}$ To date Tran-Nhut has not written at length about the Vietnam War (1954-1975) and its aftermath. Yet, interestingly, the only time she briefly mentioned the 1968 Têt Offensive and the Fall of Saigon in 1975 is when she uses these events as a backdrop to one of her short stories in Le Palais du Mandarin. In 'Secret' she highlights the continuity and vitality of Vietnamese culinary culture as it is symbolically seen through the successful protection, migration and re-implantation of a Huê's emblematic rice-based dish, the com hên, to the heart of Little Saigon in Westminster, California (Tran-Nhut 2009b: 47-56).
} 


\section{Acknowledgments}

I would like to thank Dr Dale Adams and Dr Renata Berto for their assistance in translating the German and Italian texts of criticism referred to in this paper, and for sharing their views on the topic of 'exotic' crime fiction.

\section{Reference List}

Anderson, J., Miranda, C. \& Pezzotti, B. (eds) 2012, The Foreign in International Crime Fiction. Continuum, London \& New York.

Barthes, R. 2008, 'Toward a Psychosociology of Contemporary Food Consumption,' in Food and Culture: A Reader, (eds) C. Counihan \& P. Van Esterik. Routledge, New York: 20-27.

Blanc, K. 2008, Polar. Au coeur du Vietnam du XVIIè siècle avec T.-V. Tran-Nhut. Online, available: http://tvtn.free.fr/presse/le telegramme.html [Accessed 14 December 2011].

Brown, R. B. \& Kreiser, Jr., L. A. (eds.) 2000, 'Introduction,' in The Detective as Historian: History and Art in Historical Art Fiction. Bowling Green University Popular Press, Bowling Green, OH: xiiixxvi.

Carloni, M. 2005, Vietnam: Thanh-Van Tran-Nhut. Online, available: http://thrillermagazine.it/rubriche/821/ [Accessed 6 November 2012].

Casazza, C. \& Vuillemin, P. 2011, La cuisine abominable: L'Asie en 100 recettes incroyables mais vraies. T. Hugo \& Compagnie, Paris.

Chiva, M. 1993, 'L'amateur de durian,' in La gourmandise. Délices d'un péché, C. N'Diaye. Autrement, Coll. Mutations/Mangeurs, N 140, Paris: 90-96. Online, available: http://www.lemangeurocha.com/fileadmin/contenusocha/09-amateur_de_durian.pdf [Accessed 29 April 2013].

Cosani, B. C. n.d., La literatura policial asiática entra en occidente. Online, available: http://www.revistalanegra.cl/policial/magazine/la-literatura-policial-asiatica-entra-en-occidente [Accessed 6 November 2012].

De la Bissachère, P.-J. L. 1812, Etat actuel du Tunkin, de la Cochinchine et des royaumes de Cambodge, Laos et Lac-Tho. Libraire française et étrangère de Galignani, Paris.

Docher, F. n.d., Les travers du docteur Porc. Online, available: http://www.asiexpo.com/club/chroniques show.php?no=1046\&categorie=toutes [Accessed 21 June 2012].

Dupuis, C. 2005, Interview Thanh-Van Tran-Nhut. Online, available: http://tvtn.free.fr/presse/interviewthanh-van-tran-nhut 71 entredeuxnoirs.html [Accessed 21 June 2012].

Ferniot, C. 2009, Les dix meilleurs polars de l'année. Online, available: http://tvtn.free.fr/presse/10meilleurspolars.jpg [Accessed 6 November 2012].

Fischler, C. 2001, L'homnivore. Odile Jacob, Paris.

Greenwood, K. \& Pausacker, J., 1995, Recipes for Crime. McPhee Gribble, Ringwood, VIC, Australia.

Grolleau, F. 2004, Kim Tran-Nhut, L'aile d'airain, une enquête du mandarin Tân. Online, available: http://www.fredericgrolleau.com/article-kim-tran-nhut-l-aile-d-airain---une-enquete-du-mandarintan-108168812.html [Accessed 6 November 2012].

Haining, P. (ed.). 1991, Murder on the Menu: Cordon Bleu Stories of Crime and Mystery. Souvenir, London.

Keller, B. 2008, Pulver des Kalten Büffets. Online, available: http://www.berlinkriminell.de/1/buecher_239.htm [Accessed 14 December 2011].

Knight, S. 2004, Crime Fiction 1800-2000: Detection, Death, Diversity. Palgrave Macmillan, New York.

Koß, B. 2008, Die Geschichte Vietnams als Krimistoff. Online, available: http://www.dradio.de/dkultur/sendungen/kritik/809990/ [Accessd 14 December 2011].

Krajenbrink, M. \& Quinn, K. M. (eds.) 2009, Investigating Identities: Questions of Identity in Contemporary International Crime Fiction. Editions Rodopi, Amsterdam/New York.

Laherrère, J.-M. 2009, Les oubliés du top 100: les soeurs Tran-Nhut. Online, available: http://actu-dunoir.over-blog.com/article-29679246.html [Accessed 14 December 2011].

Lefèvre, K. 1990, Retour à la saison des pluies. Editions Bernard Barrault, Paris.

Lévi-Strauss, C. 1964, Mythologiques: le cru et le cuit. Plon, Paris.

Manson, C. (ed.), 1994, Crime à la Carte. Penguin, New York.

Matzke, C. \& Mühleisen, S. 2006, 'Introduction: The “Anatomy” of Crime Writing,' in Postcolonial Postmortems: Crime Fiction from a Transcultural Perspective, (eds) C. Matzke \& S. Mühleisen. Editions Rodopi, Amsterdam \& New York: 1-16. 
Mauvais genres 2004, Réponses des soeurs Tran-Nhut aux questions des abonnés de la liste de discussion. Online, available: http://tvtn.free.fr/mauvais_genres/reponses_des_soeurs_trannhut.htm [Accessed 14 December 2011].

McConnell, F. 2009, 'The Later Eaton Essays,' in The Science of Fiction and the Fiction of Science: Collected Essays on SF Storytelling and the Gnostic Imagination, (ed.) G. Westfahl. McFarland, Jefferson, NC: 111-24.

Messent, P. B. (ed.), 1997, 'Introduction: From Private Eye to Police Procedural—The Logic of Contemporary Crime Fiction,' in Criminal Proceedings: The Contemporary American Crime Novel, (ed.) P. Messent. Pluto, London \& Chicago: 1-21.

Meudal, G. 2000, L'ombre du prince, une enquête du mandarin Thân [sic]. Online, available: http://tvtn.free.fr/presse/Radio_France_critiquegmeudal.htm [Accessed 6 November 2012]. 2002, Le mandarin mène sa barque. Online, available: http://tvtn.free.fr/presse/presse.html [Accessed 14 December 2011].

Patzer, G. 2008, 'Die bösen Geister sind los: Eine neue Krimireihe erzählt von Drogen und Toten in Vietnam.' Online, available: http://www.literaturkritik.de/public/rezension.php?rez id=11760 [Accessed 21 June 2012].

Pelletier, C. n.d., Exquis d'écrivain. Online, available: http://chantalpelletier.free.fr/exquis [Accessed 11 February 2013].

Porter, D. 1981, The Pursuit of Crime: Art and Ideology in Detective Fiction. Yale University Press, New Haven/London.

Poulain, J.-P. 1997, 'La nourriture de l'autre: entre délices et dégoûts,' in Cultures, nourriture. Internationale de l'imaginaire, vol. 7. Actes Sud, Paris: 115-39.

Pyrhönen, H. 1994, Murder from an Academic Angle: An Introduction to the Study of the Detective Narrative. Camden House, Columbia.

Régnier, F. 2004, L'exotisme culinaire. Presses Universitaires de France, Paris.

Reid, R. A. 1992, 'The Centenary Caper: Casing Two Competing Schools of Detective Fiction,' Rocky Mountain Review of Language and Literature, vol. 46, no. 1/2: 55-62.

Rudolf, D. P. (2008), 'Flucht in die Gegenwart.' Online, available: http://titelmagazin.com/artikel//4638.html [Accessed 6 November 2012].

Sarrot, J.-C. \& Broche, L. 2009, Le roman policier historique. Nouveau monde éditions, Paris.

Scaggs, J. 2005, Crime Fiction. Routledge, London \& New York.

Todorov, T. 1971, Poétique de la prose. Editions du Seuil, Paris.

Tran-Nhut, T.-V. 1999, Le temple de la grue écarlate. Editions Picquier, Arles. 2007, Les travers du docteur Porc. Editions Picquier, Arles. 2009a, Le bol fumant de la félicité. Online, available: http://www.liberation.fr/vous/0101554729le-bol-fumant-de-la-felicite [Accessed 21 June 2012]. 2009b, Le palais du mandarin. Nil Editions, Paris. 2011, Les corbeaux de la mi-automne. Editions Picquier, Arles.

Verdaguer, P. 2001, 'The Politics of Food in Post-WWII French Detective Fiction,' in French Food: On the Table, on the Page, and in French Culture, (eds.) L. R. Schehr \& A. S. Weiss. Routledge, New York: 184-202.

Winks, R. W. (ed.) 1969, The Historian as Detective: Essays on Evidence. Harper \& Row, New York. (ed.) 1980, 'Introduction,' in Detective Fiction: A Collection of Critical Essays. PrenticeHall/Spectrum, Englewood Cliffs, NJ: 1-14. 